\title{
Bendamustin ile indüklenen HL60 hücre serisinde apoptozun ve hücre döngüsünde görevli genlerin ekspresyon değişimlerinin belirlenmesi
}

\author{
Determination of apoptosis and changes on cell cycle genes expressions in HL60 cell \\ line induced with bendamustine
}

\author{
Sezgi Kıpçak, Nur Selvi Günel
}

Gönderilme tarihi: 18.04 .2018

Kabul tarihi: 08.08.2018

Özet

Amaç:Akut miyeloid lösemi (AML), hematopoetik öncül hücrelerin heterojen klonal bir hastalığıdır. Akut promiyelositer lösemi (APL), bir AML alt tipidir ve morfolojik olarak anormal promiyelositler ile karakterize edilir. APL'de görülen en belirgin kromozom düzensizliği ise 15. kromozomdaki promyelositik lösemi (PML) geni ile 17. kromozomdaki retinoik asit reseptör (RAR) alfa geninin translokasyonu sonucu bir füzyon proteini oluşturmasıdır. Bendamustin suda çözünebilen, beyaz, nitrojen hardal grubu ve bütirik asit yan zinciri bulundurması nedeniyle amfoterik özellik özellik gösteren mikrokristallin tozudur. Alkilleyici ajan olan bendamustin aynı zamanda pürin analoğu özelliği gösterir ve diğer alkilleyici ajanlara göre toksisite profili daha ılımlıdır. Bu çalışmada, bendamustinin APL hücre serisi olan HL60 hücreleri üzerindeki sitotoksik, sitostatik ve apoptotik etkileri incelenmiş ve hücre döngüsü, mitotik katastrof ve apoptoz ile ilişkili genlerinin ilaç ile muamele sonrasındaki ekspresyon değişimleri belirlenmiştir.

Gereç ve yöntem: Çalışmamızda bendamustinin APL'ye model oluşturan HL60 hücreleri üzerindeki sitotoksik etkisini WST-1 testi ile, apoptotik etkisini Annexin $V$ ve Apo Direct Tunnel methoduyla, sitostatik etkisini ise Cycletest Plus DNA Reagent Kit ile değerlendirilmiştir. Ayrıca bendamustinin HL60 hüce serilerindeki hücre döngüsü, mitotik katastrof ve apoptoz ile ilişkili genlerinin mRNA ekspresyonlarına etkisi kantitatif RT-PCR ile rölatif olarak belirlenmiştir.

Bulgular: Bendamustinin sitotoksik etkisinin HL60 hücre serisi üzerinde yüksek dozlarda etkili olduğu belirlenmiştir. Bununla birlikte, apoptotik etkisinin her iki yöntem ile de doza bağımlı olarak anlamlı bir şekilde arttığı belirlenmiştir. Bendamustin ile 48 saat muamele sonrasında HL-60 hücrelerinde apoptoz ile ilişkili olduğu bilinen CASP3, CASP8, CASP9 ekspresyonlarını sırasıyla 2.4, 5.7, 6.8 kat arttırdığı saptanmıştır. Ayrıca mitotik katastrofi ile ilişkili olduğu bilinen Plk1 ekspresyonun 2.5 kat azaldığını ve tümör supresör olduğu bilinen Plk2 ekspresyonunda ise 17 katlık bir artma belirlenmiştir.

Sonuç: Bulgularımız, bendamustinin apoptoz ve mitotik katastrof gibi hücre ölüm mekanizmaları üzerinde etkili olduğunu ve APL' nin tamamlayıcı tedavisinde alternatif bir tedavi olarak kullanılabileceğini göstermektedir.

Anahtar sözcükler: AML, APL, Bendamustin, apoptozis

Kıpçak S, Günel NS. Bendamustin ele indüklenen HL60 hücre serisinde apoptozun ve hücre döngüsünde görevli genlerin ekspresyon değişimlerinin belirlenmesi. Pam Tıp Derg 2018;11(3);251-260.

\begin{abstract}
Purpose:Acute myeloid leukemia ( $A M L)$, is a heterogeneous clonal disorder of hematopoietic progenitor cells. Acute promyelocytic leukemia (APL), is a subtype of AML and characterized by aberrant morphology of promyelocytes. The most specific chromosomal disorder that occurs in APL patients is $(15 ; 17)$ translocation. This translocation the promyelocytic leukemia $(P M L)$ gene on chromosome 15 and the retinoic acid receptor (RAR) alpha gene on chromosome 17 fuse and produce a PML-RAR $\alpha$ fusion protein. Bendamustine is a water soluble, white, microcrystalline powder with amphoteric properties due to a nitrogen mustard group and a butyric acid side chain. Bendamustine acts as an alkylating agent and also has purine analog activity. Bendamustine has more moderate toxicity profile than the other alkylatingg agents. In our study, it is aimed to investigate cytotoxic, cytostatic and apoptotic effects of bendamustine on APL cell line HL60. Also we aime to evaluate the effect of bendamustine on HL60 cells according to the expression of genes including several signal transduction pathways such as; cell cycle, mitotic catastrophe and apoptosis,

Materials and methods: Cytotoxic effect of bendamustine on HL60 cell line was assessed by WST-1 assay, apoptotic effect by Annexin V and Apodirect Tunnel assay and cytostatic effect by Cycletest Plus DNA Reagent Kit. Also the effect of bendamustine on expression levels of several cell cycle, mitotic catastrophe and apoptosis related genes in HL60 was determined by quantitative RT-PCR relatively.
\end{abstract}

Sezgi Kıpçak, Doktora Öğrencisi Ege Üniversitesi Tıp Fakültesi Tıbbi Biyoloji Anabilimdalı, IZMiR, e-posta: kipcaksezgi@gmail.com (orcid. org/0000-0003-0615-3844)

Nur Selvi Günel, Dr.Öğr.Üyesi, Ege Üniversitesi Tıp Fakültesi Tıbbi Biyoloji Anabilimdalı Bornova/IZMiR, e-posta: selvi.nur@gmail.com (orcid. org/0000-0003-0612-2263) (Sorumlu yazar) 
Results: We determined that bendamustine has cytotoxic effect on HL60 cell line with high-dose treatment. Also we found that Bendamustine significantly induces apoptosis in dose dependent manner and has no cytostatic effects on HL60 cells. After the 48 hours treatment with bendamustine, expression levels of apoptosis related CASP7, CASP8, CASP9 genes were upregulated 2.4, 5.7, 6.8 fold in HL60 cells, relatively. Also expressions of mitotic catastrophe related genes Plk1downregulated 2.5 fold and Plk2 which as known as tumor suppressor gene, upregulated 17 fold.

Conclusion: Our data suggest that Bendamustine is effective on cell death mechanisms such as apoptosis ve mitotic catastrophe and can be used in supplement as a alternative treatment.

Key words: AML; APL; apoptosis, Bendamustin

Kıpçak S, Günel NS. Determination of apoptosis and changes on cell cycle genes expressions in HL60 cell line Induced with bendamustine. Pam Med J 2018;11(3):251-260.

\section{Giriş}

Erişkinlerdeki akut lösemilerin çoğunu (yaklaşık \%70-80) akut miyeloid lösemi (AML) oluşturmaktadır. Akut promiyelositer lösemi (APL) ise AML'lerin \%10-15'ini oluşturmaktadır. APL, AML'nin French-American-British (FAB) sınıflandırmasında M3 olarak belirtilen alt tipidir. APL oluşumunda farklı birçok faktörün etkili olduğu bilinmektedir. En karakteristik olanı, 15. kromozomdaki promiyelositik lösemi (PML) geni ile 17. kromozomdaki retinoik asit reseptör (RAR) alfa geninin translokasyonu sonucu bir füzyon proteini oluşturmasıdır.

Bendamustin ilk olarak 1963 yılında Ozegowski ve Krebs tarafından doğu Almanya'da sentezlenmiştir. Suda çözülebilen, beyaz renkli, mikrokristalli toz formundadır ve azot hardal grubu ve bütirik asit yan zincirleri nedeniyle amfoterik özellik göstermektedir. Kimyasal formülü "4-\{5-[bis(2-kloroetil)amino]1-metil-2-benzimidazolil\}butirik asit"dir. Bir azot hardal bölgesi, bir benzimidazol halkası ve bir alkan karboksilik asit yan zinciri içermektedir bu yapıların tümünün ilacın sitotoksik aktivitesinden sorumlu olabileceği düşünülmektedir [1, 2]. Bendamustin, iki DNA zinciri arasında veya tek bir DNA zinciri içindeki bazlar arasında çapraz bağ oluşumuna neden olan bir alkilleyici ajan olarak rol oynamaktadır [3] . Diğer alkilleyici ajanlarla karşılaştırıldığında, bendamustin daha fazla çapraz bağa neden olmakta, daha da önemlisi bendamustinin oluşturduğu çapraz bağlar carmustine ve siklofosfamidinin oluşturduğu çapraz bağlara kıyasla daha dayanıklı ve tamir edilmesi daha güç olmaktadır [4]. Henüz in vivo olarak kanıtlanmış olmasa da, benzimidazol halkası bendamustinin pürin analog aktivitesinden sorumlu olabilir. Bendamustin diğer alkilleyici ajanlardan farklı bir etki mekanizmasına sahiptir; DNA hasar stres yanıtının ve apoptozun aktivasyonu, mitotik kontrol noktalarının inhibisyonu ve mitotik katastrofun indüklenmesidir [5].

Çalışmada alkilleyici bir ajan olan aynı zamanda pürin analoğu özelliği gösteren bendamustinin akut promiyeloid lösemi hücre hattı HL60 ile muamelesi sonrası apoptotik, sitotoksik etkileri incelenecektir. Ayrıca lösemi oluşumunda önemli olduğu bilinen mitotik katastrofi, hücre döngüsü, apoptozda görevli genlerin ekspresyon profil değişimleri üzerindeki etkisi belirlenmiştir.

\section{Gereç ve yöntem}

\section{Hücre Kültürü}

Çalışmamızda akut promiyeloid lösemiye model olan HL60 hücre serisi (Sigma Aldrich) kullanılmıştır. Akut promyeloid lösemi hücre dizisi, uygulanacak işlemlere hazırlamak için 25 $\mathrm{cm}^{2}$ lik flasklar içerisine ekilmiştir. Kültür ortamı olarak RPMI 1640 (Biological Industiries), \%10 Fetal Sığır Serumu (FBS), \%1 L-glutamin (2 $\mathrm{mM}), \% 1$ Penisilin/Streptomisin kullanılmıştır. Hücrelerden yeterli üreme elde edilene kadar $37^{\circ} \mathrm{C}$ 'de $\% 95$ nem ve $\% 5 \mathrm{CO}_{2}$ 'li etüvde inkübe edilmiştir. Hücrelerin proliferasyonu ve pasajları inverted mikroskop kullanılarak düzenli olarak takip edilmiştir. Hücrelere 10, 30, 50, $100 \mu \mathrm{g} /$ $\mathrm{ml}$ konsantrasyonlarda bendamustin (Cat no \#0272M4731V, Sigma Aldrich), etken maddesi uygulanmıştır ve etken madde verilmeyen hücre grubu, kontrol grubu olarak değerlendirmeye alınmıştır. Bendamustin konsantrasyonu, $13 \mathrm{mM}$ olacak şekilde DMSO'da çözülmüştür.

\section{Sitotoksisite analizi}

Ticari olarak temin edilen etken maddenin hücre serisi üzerindeki sitotoksik etkisini belirlemeküzereWST-1 (WST-1 Cell Proliferation 
Reagent, Roche) yöntemi uygulanmıştır. Model lösemi hücreleri her kuyucukta $3 \times 10^{4}$ hücre olacak şekilde 96-kuyucuklu plakalara dağıtılmıştır. Ardından hücreler üzerine $10 \mu \mathrm{g} / \mathrm{ml}$ - $100 \mu \mathrm{g} / \mathrm{ml}$ aralığında etken madde eklenmiştir. Etken madde eklenmeyen örnek kontrol olarak kabul edilmiştir.

\section{Apoptoz analizleri}

HL60 hücre serisi, bendamustinin farklı konsantrasyonları ile muamele edilmiş ve 24 , 48. ve 72. saat sonunda hücreler üzerindeki apoptotik etkileri Annexin V EGFP Apoptosis Detection Kiti (Biovision) ve ApoDirect In Situ DNA Fragmentation Assay Kit'i (Becton Dickinson) ile araştırılmıştır. Etken madde ile muamele edilmeyen grup kontrol grubu olarak kabul edilmiştir. Her bir gün için ayrı kontrol örneği ile çalışılmıştır. Apoptoz analizleri, iki farklı yöntem ile üç tekrar yapılarak çalışıımıştır.

\section{Real Time PCR ve Gen Ekspresyon Analizi}

$100 \mu \mathrm{g} / \mathrm{ml}$ bendamustin uygulanan ve ilaç uygulanmayan kontrol hücrelerinden 48 saat sonra mirVana ${ }^{\mathrm{TM}}$ miRNA Isolation Kit'i (Ambion) kullanılarak total RNA'ları elde edilmiştir. Elde edilen total RNA örneklerinden Transcriptor High Fidelity cDNA Synthesis Kit'i kullanılarak cDNA'lar sentezlenmiştir. Sentezlenen cDNA'lar kalıp olarak kullanılarak hücre döngüsü, apoptoz çalışmaları yapılmış ve mitotik katastrofide görev alan genlere ait ekspresyon analizleri real-time PCR cihazı (ABI-7500 fast Real-Time PCR Applied Biosystems) ile gerçekleştirilmiştir. Yapılan bütün real-time PCR amplifikasyonlarında dört farklı kontrol (18S-GAPDH-HPRT-GUSB) kullanılmıştır. İstatistiksel analizler $2^{-\Delta \Delta C t}$ metodu aracılığıyla, çoklu kontrol gen ekspresyonu temel alınarak hesaplanmıştır.

\section{Bulgular}

Bendamustinin hücre canlılığı üzerine etkilerinin değerlendirilmesi

Bendamustinin hücreler üzerindeki sitotoksik etkisini belirlemek amacıyla $10,30,50$ ve 100 $\mu \mathrm{g} / \mathrm{ml}$ 'lik konsantrasyonları 48 . saatte WST-1 testi ile değerlendirilmiştir (Grafik 1).

Bendamustinin HL60 hücre serisi üzerindeki apoptotik etkisinin değerlendirilmesi

Bendamustinin 10, 30, 50, $100 \mu \mathrm{g} / \mathrm{ml}$ 'lik konsantrasyonları kullanılarak 24., 48. ve 72. saatlerde HL60 hücreleri üzerindeki apoptotik etkileri, Annexin $V$ ve Apo Direct Tunnel yöntemleri kullanılarak değerlendirilmiştir. Tüm apoptoz deneyleri başlangıçta $3 \times 10^{5}$ hücre/ $\mathrm{ml}$ olacak şekilde hazırlanmış ve 3 tekrarlı olarak çalışılmıştır. Etken madde ile muamele edilmeyen hücreler kontrol grubu olarak kullanılmış ve çalışma grubu ile karşılaştırarak bendamustinin tetiklediği apoptoz düzeyindeki artış belirlenmiştir. Her iki yöntemde de apoptotik hücre sayısı artan konsantrasyonlara bağlı olarak yükselmiştir (Grafik 2), (Grafik 3).

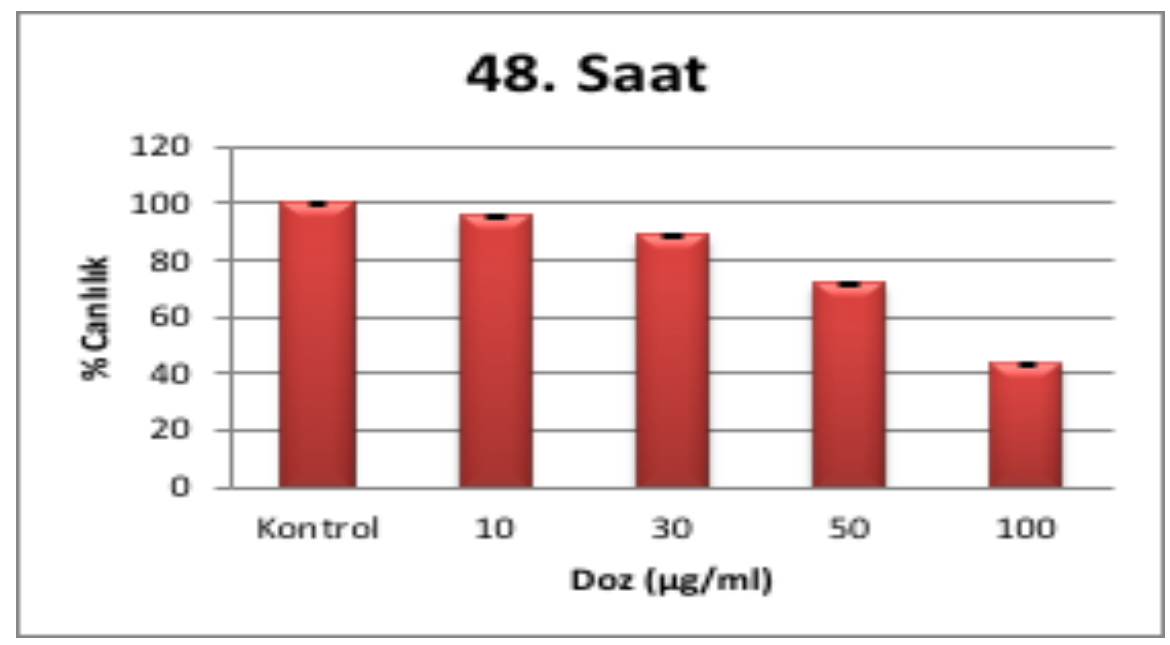

Grafik 1. HL60 hücrelerinde bendamustinin sitotoksisitesi 
A

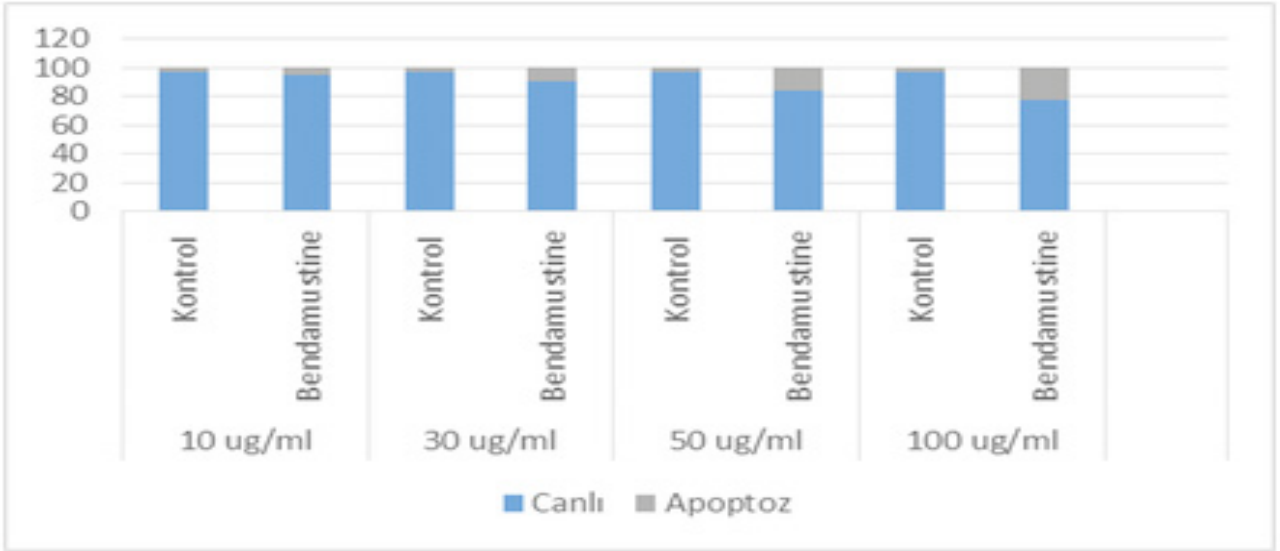

B

C01 HL60 Kontrol Benda
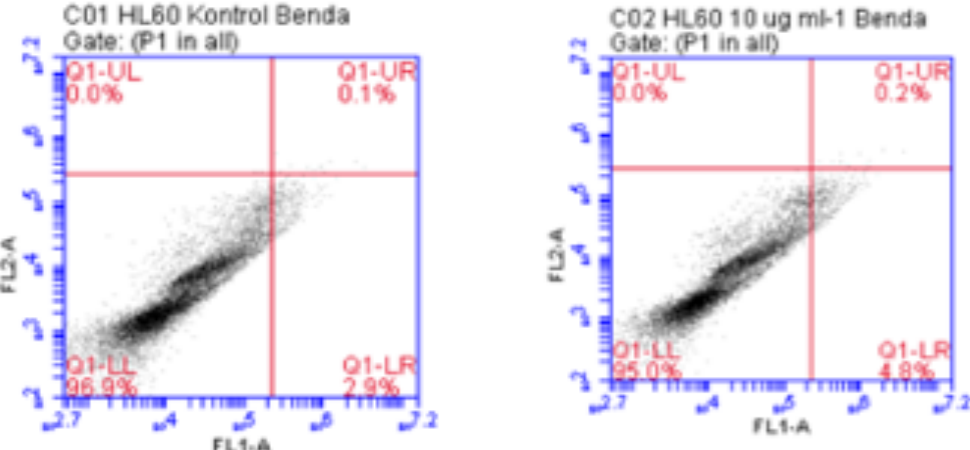

C03 HL60 30 ug ml-1 Benda

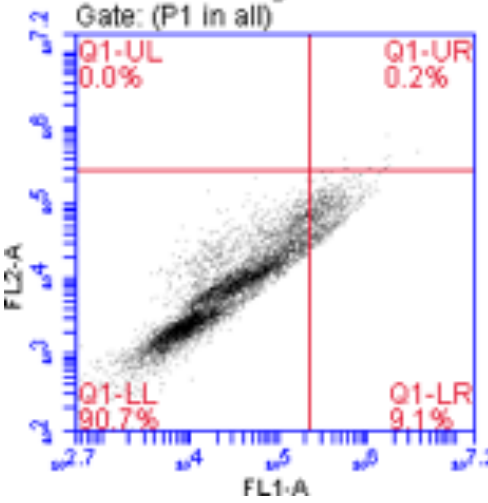

B04 HL60 50 ug ml-1 Benda

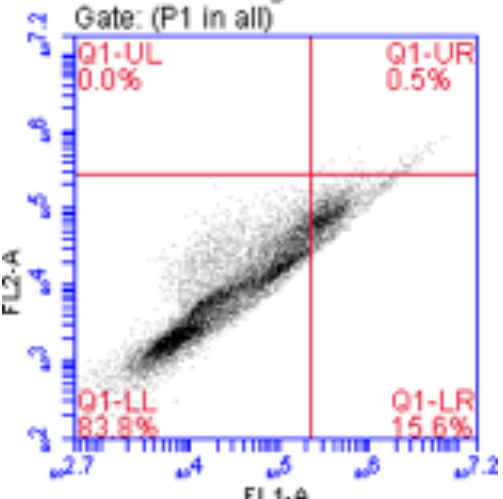

C05 HL60 100 ug ml-1 Benda

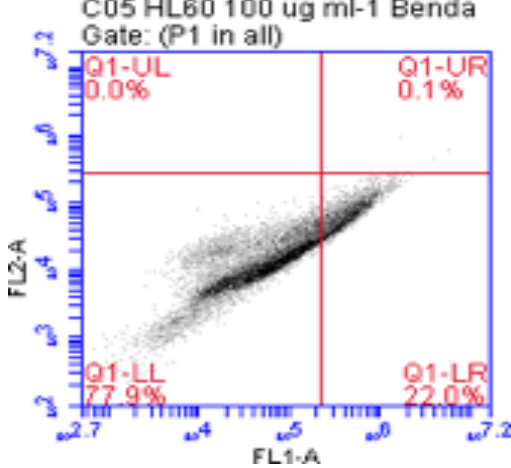

Grafik 2. Bendamustinin HL60 hücre serisindeki apoptotik etkisinin; $A$ : Annexin $\vee$ testi ile değerlendirilmesi B: Akım sitometri görüntüleri. Sol alt: canlı, sağ alt: erken apoptotik sağ üst: geç apoptotik, sol üst: nekrotik hücrelerin yüzdesini göstermektedir. 
A

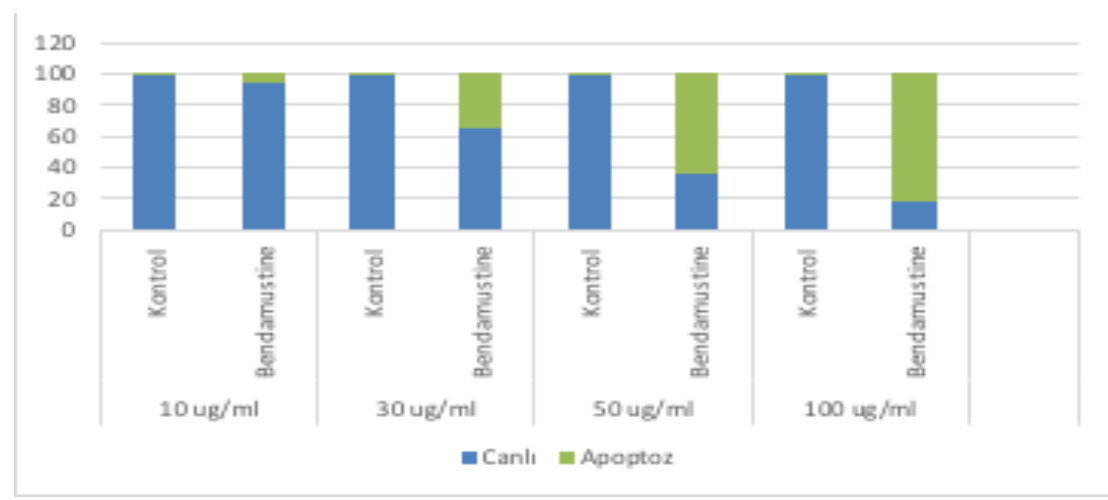

B

B03 HL60 30 ug ml-1 Benda Gate: (P2 in all)

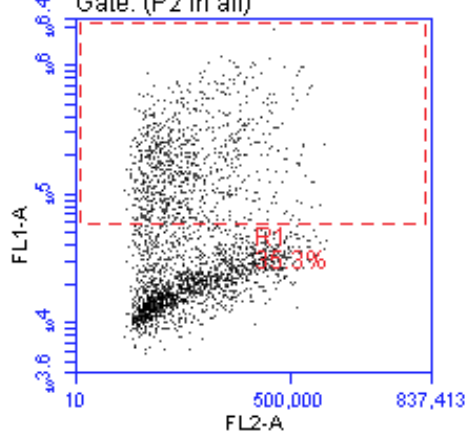

B05 HL60 100 ug ml-1 Benda

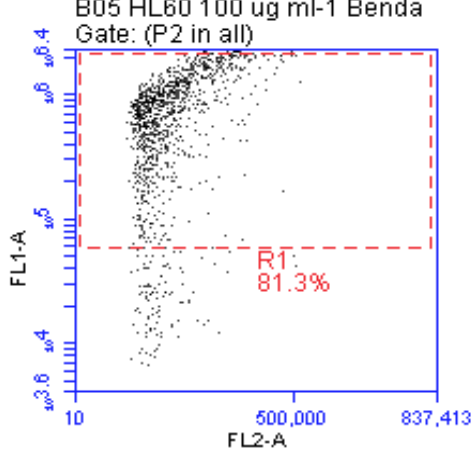

B05 HL60 100 ug ml-1 Benda

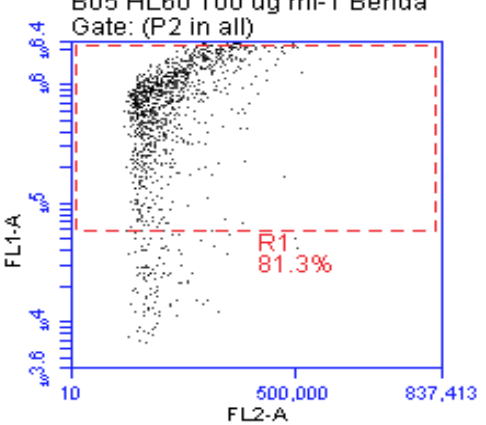

B01 HL60 Kontrol Benda

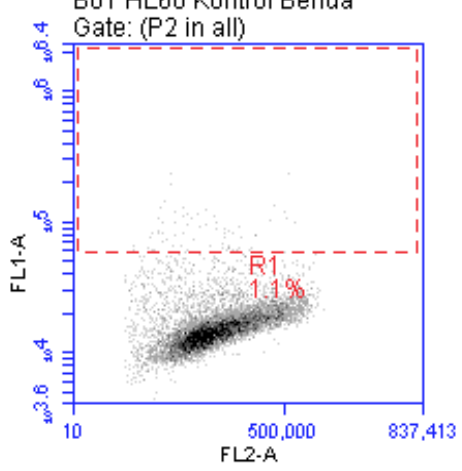

B02 HL60 10 ug ml-1 Benda

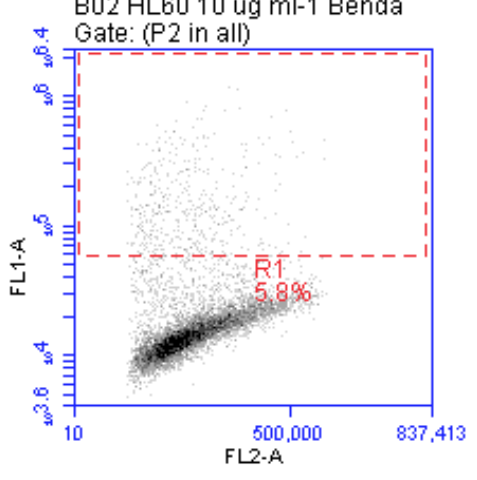

Grafik 3. Bendamustinin HL60 hücre serisindeki apoptotik etkisinin; A: Apo Direct Tunnel yöntemiyle değerlendirilmesi. B: Akım sitometri görüntüleri. Alt: canlı, üst: apoptotik hücrelerin yüzdesi göstermektedir.. 
HL60 Hücre Dizisinde Bendamustinin Gen Ekspresyon Düzeyleri Üzerindeki Etkisi

Bendamustinin etken konsantrasyonu olan $100 \mu \mathrm{g} / \mathrm{ml}$ 'nin oluşturduğu ve apoptoz, hücre döngüsü, mitotik katastrofi ile ilişkili genlerin ekspresyon değişimleri 48. saatte değerlendirilmiştir. Kontrol grubuna göre bendamustinin oluşturduğu gen ekspresyon değişimleri belirlenmiştir. Gen ekspresyon analizleri 3 tekrarlı olarak gerçekleştirilmiştir (Tablo 1).

Tablo 1. Bendamustin ile muamele edilmiş HL60 hücre serisinde ekspresyonları anlamlı olarak artan veya azalan genlerin kat değişimleri ve p değerleri

\begin{tabular}{lll}
\hline Gen & Kat & p değeri \\
\hline CASP3 & 2.4539 & 0.000586 \\
CASP7 & 3.2897 & 0.00012 \\
CASP8 & 5.7024 & 0.000447 \\
CASP9 & 6.8015 & 0.006723 \\
CARD10 & 11.1928 & 0.000024 \\
\hline
\end{tabular}

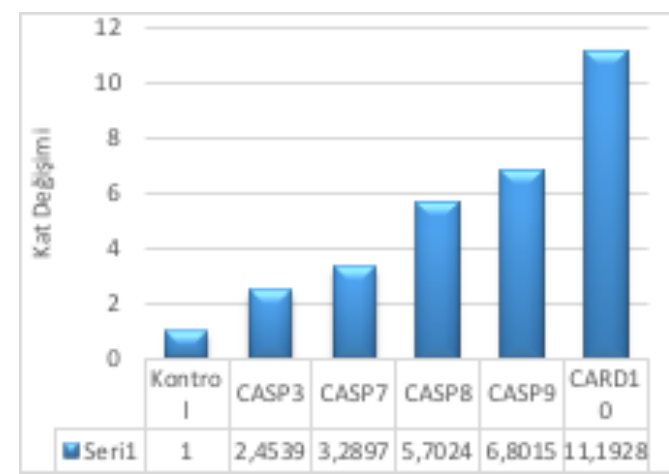

\begin{tabular}{lll}
\hline Gen & Kat Değişimi & $p$ değeri \\
\hline NOXA & 4.6007 & 0.000152 \\
BAK1 & 70.6595 & 0.018842 \\
BAX & 2.4075 & 0.001674 \\
\hline
\end{tabular}

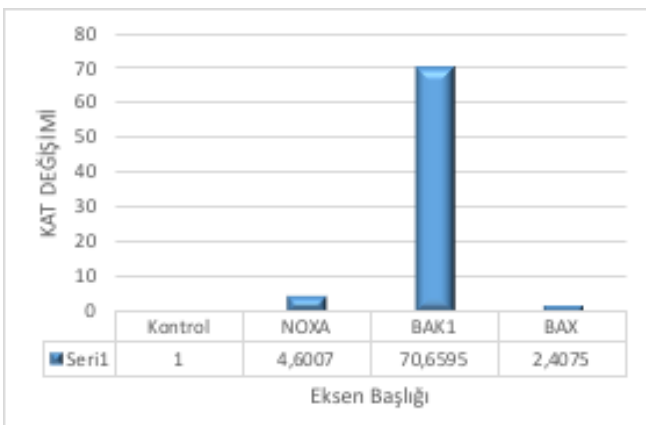

\begin{tabular}{lll}
\hline Gen & Kat Değişimi & $p$ değeri \\
\hline P21 & 54,5886 & 0,00066 \\
Myc & $-13,4729$ & 0,002178 \\
ATM & 8,2045 & 0,000167 \\
\hline
\end{tabular}




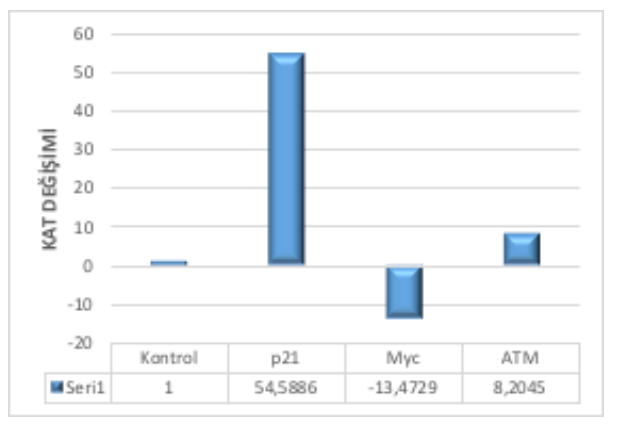

\begin{tabular}{lll}
\hline Gen & Kat Değişimi & $p$ değeri \\
\hline PLK1 & -7.5687 & 0 \\
PLK2 & 23.1702 & 0 \\
Siklin B1 & -12.9748 & 0.040014 \\
\hline
\end{tabular}

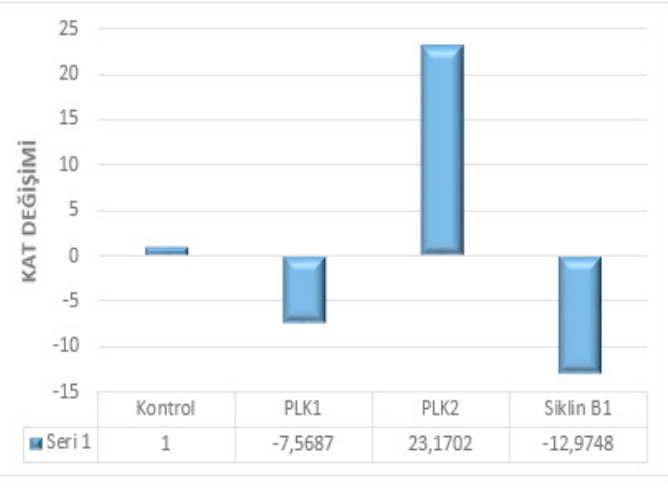

Tablo 1 (devamı). Bendamustin ile muamele edilmiş HL60 hücre serisinde ekspresyonları anlamlı olarak artan veya azalan genlerin kat değişimleri ve $p$ değerleri

\section{Tartışma}

Yapılan çalışmalarda; alkilleyici bir ajan olan bendamustinin aynı zamanda pürin analoğu özelliği gösterdiği ve çeşitli kanser hücrelerine karşı sitotoksik etkisi olduğu bildirilmiştir. Nitrojen hardal kısmına, benzimidazol halkasına ve alkan karboksilik asit yan zincirine sahip olmasının sitotoksik aktivitesine etkisinin olabileceği düşünülmektedir [6,7]. Bendamustin alkilleyici ajan olarak, DNA bazları arasında çapraz bağ oluşumunda rol oynamaktadır [8]. Bendamustin, insan tümör hücre kültürleri üzerinde diğer alkilleyici ajanlardan farklı bir aktivite profili göstermektedir. Aktif madde en azından kısmen kalıcı DNA etkileşimine bağı olarak, farklı direnç mekanizmaları olan insan tümör kültür hücrelerinde çapraz direnç oluşturmamış veya oldukça düşük çapraz direnç oluşturmuştur. Bendamustin, kronik lenfositik lösemi ve non-Hodgkin lenfoma tedavisinde kullanılmaktadır [9].

Bu çalışmada amacımız ilk adımda; APL için model oluşturan HL60 hücre serisinde bendamustin kullanımına bağlı olarak olası sitotoksik, apoptotik ve sitostatik etkiyi belirlemektir. İkinci adımda ise; ilacın sitotoksik etkisinin anlamlı bulunduğu saat diliminde mikroarray olarak tasarlanan apoptoz, hücre döngüsü ve mitotik katastrofi ile ilişkili olduğu bilinen genlerin ekspresyonları üzerindeki etkisini göstermektir.

Öncelikle, bendamustinin hücreler üzerindeki olası sitotoksik etkisi araştırılmıştır. Çalışmamızın sonucunda bendamustinin HL60 hücreleri üzerinde ancak yüksek konsantrasyonlarda sitotoksik etki yarattığı saptanmıştır. Bendamustinin sitotoksik etkisini 
araştıran birçok çalışma bulunmaktadır. Ancak hepsinin sonunda varılan genel yargı, ilacın yüksek konsantrasyonlarda sitotoksik özellik gösterdiğidir. Gaul ve ark. [10] multiple miyeloma hücre serileri ile yaptıkları çalışmada bendamustinin 35-65 $\mu \mathrm{g} / \mathrm{ml}$ konsantrasyonlarının sitotoksik etki gösterdiğini saptamışlardır. Roue ve ark. [11] mantle hücreli lenfoma ve kronik lenfositik lösemi hücreleri ile yapmış oldukları çalışmada bendamustinin tek başına düşük konsantrasyonlarda sitotoksik etki göstermediğini ancak fludarabin ile kombine olarak kullanımı sonucunda sitotoksik etkinin oluştuğunu bildirmişlerdir. Hiraoka ve ark. [5] 2014'te yayınladıkları çalışmalarında bendamustinin $100 \mu \mathrm{M}^{\prime} ı$ n üzerindeki konsantrasyonlarında $I_{50}$ değerine ulaştıklarını belirtmişlerdir. Bizim çalışmamızda da benzer şekilde bendamustin ancak yüksek konsantrasyonda sitotoksik etki göstermiştir.

Çalışmanın devamında bendamustinin hücreler üzerindeki apoptotik etkisi, Annexin $\checkmark$ ve Apo Direct Tunnel olmak üzere iki farklı yöntem ile araştırılmıştır. Buradaki amaç, apoptozu çeşitli sinyal yolakları aracılığıyla tetiklediği bilinen bendamustinin HL60 hücreleri üzerindeki apoptotik etki düzeyini saptamaktır. Her iki yöntem ile bendamustinin kontrole oranla konsantrasyona bağımlı bir şekilde apoptozu tetiklediği belirlenmiştir. Apo Direct Tunnel yöntemiyle yapılan apoptoz deneyi ile Annexin $\mathrm{V}$ yöntemiyle yapılan apoptoz deneyini kıyasladığımızda, DNA kırık oluşumunu tespit eden Apo Direct Tunnel yönteminde konsantrasyonla orantılı olarak daha yüksek oranda apoptotik hücre bulunduğu saptanmıştır. Bu farklılığın nedeninin DNA hasarına neden olan bendamustinin etki mekanizmasından kaynaklandığı düşünülmektedir. Schwanen ve ark. [12] kronik lenfositik lösemi hücre serileriyle yaptıkları çalışmalarındaki bendamustinin apoptotik etkisi ilgili ile sonuçları bizim çalışmamızla benzerlik göstermektedir.

Bendamustinin apoptozu tetiklediği belirlenmiştir. Literatürlerdeki veriler bu durumun birçok sinyal yolağı ile ilişkili olabileceğini vurgulamaktadır. $\mathrm{Bu}$ nedenle çalışmada 48 saat boyunca bendamustinin 100 $\mu \mathrm{g} / \mathrm{ml}$ 'lik konsantrasyonu ile muamele edilen HL60 hücre serisindeki gen ekspresyonları ile bendamustinle muamele edilmeyen kontrol grubu karşılaştırıldığında, apoptoz, hücre döngüsü ve mitotik katastrofi ile ilgili genlerin önemli bir kısmında anlamlı değişimler söz konusudur.

Hücre proliferasyonunda önemli bir rolü olduğu bilinen myc proteininin ekspresyonu lösemi ve lenfoma hücrelerinde artmış durumdadır. Yapılan çalışmada HL60 hücre serisinde bendamustin ile 48 saat muamele sonrasında myc ekspresyonunun 13,4 kat azaldığı saptanmıştır. Bu azalma bendamustinin myc onkogeninin ekspresyonunu baskılayarak proliferasyon-apoptoz arası regülasyonu sağladığını düşündürmektedir. Çalışmamıza benzer şekilde, Yang ve ark. [13] mantle hücreli lenfoma hücre hattına pim kinaz inhibitörü olan SGI-1776 ile bendamustini kombine olarak uygulamışlar ve myc ekspresyonunda önemli bir azalma kaydetmişlerdir.

Çalışmada; intrinsik apoptotik yolakta DNA hasarına yanıt olarak ifadesi artan noxa geninin ekspresyonunun HL60 hücrelerinin bendamustin ile 48 saat muamelesi sonrasında 4,6 kat arttığı belirlenmiştir. Bendamustin'in iki etki mekanizması göz önüne alındığında; alkilleyici ajan olan bendamustin DNA hasarı oluşturarak kanser hücrelerinin proliferasyonunu önler ve bir antimetobolit gibi görev yaparak hızlı bir şekilde yeni DNA sentezini sağlar. Sonuçlar bu mekanizmayı desteklemektedir. Leoni ve ark. [14] lenfoma hücre serisi olan SU$\mathrm{DHL}-1$ hücrelerini bendamustin ile muamele ettiklerinde, NOXA geninin ekspresyonu üzerinde çalışmamızla korele sonuçlar elde etmişlerdir [15]. Yine intrinsik apoptotik yolak sinyalizasyonunda görev aldığı bilinen sitokrom c'nin mitokondri dış membranında salınımını indükleyen bax ve bak genlerinin ekspresyonlarının sırasıyla 2.4 kat ve 70 kat artmış olduğu belirlenmiştir. Roue ve ark. [11] p53 defektli KLL ve mantle hücreli lenfoma hücre serilerinin bendamustin ile muamele edilmesi sonucunda $B A X$ ve $B A K$ ekspresyonlarında artış saptadıklarını belirtmişlerdir. Bu sonuçlar, bendamustin'in HL60 hücrelerini apoptoza götürdüğünü göstermektedir.

İntrinsik apoptotik yolakta sitokrom c ile apoptozom kompleksi oluşturduğu bilinen ve kaspaz 3'ün aktivasyonunu sağlayan kaspaz 9 ekspresyonu 6.8 kat artmıştır. Hem ekstrinsik hem de intrinsik yolak ile aktive edilebilen kaspaz 3 ekspresyonu ise 2.4 kat artmıştır. Ekstrinsik apoptotik yolakta, hücre ölüm alanları 
aracılığıyla aktifleşen kaspaz 8'in, kaspaz kaskadını başlattığı bilinmektedir. Çalışma sonucunda kaspaz 8 ekspresyonu 5,7 kat artmıştır. Cai ve ark. [15] HDAC inhibitörü olan etinostat ve bendamustinin sinerjistik etkisini multiple miyeloma hücre hatlarında araştırdıkları çalışmalarında, kaspaz 8 ve kaspaz 3' ün ekspresyonlarının arttığını saptamışlardır. Elde edilen sonuçlara göre, bendamustinin kaspaz bağımlı apoptotik yolak ile apoptozu indüklediğini söyleyebiliriz.

HL60 hücrelerinin bendamustin ile muamele edilmesi sonrasında siklin bağımlı kinaz inhibitörü olarak tanımlanan, apoptoz ve hücre döngüsü kontrolünde önemli role sahip olduğu bilinen p21 geninin ekspresyonunda 54 katık bir artış olduğunu tespit ettik. p21 geni tarafından regüle edilen ve DNA hasarı sonucunda tetiklenen sinyal ileti kaskadında aktif bir role sahip olan atm geninin ekspresyonu ise 8,2 kat artmıştır. Gaul ve ark. [10] 4 miyeloma hücre serisi ile yapmış oldukları çalışmada p21 ve atm gen ekspresyonlarındaki değişimlerde çalışmamız ile benzer sonuçlar belirlemişlerdir. Ayrıca elde edilen sonuçlar doğrultusunda bendamustinin atm-p53-p21 sinyal yolu aracılığı ile hücre döngüsünün G2 evresinde arreste neden olduğunu bildirmişlerdir.

Hatalı mitoz sırasında veya hemen sonrasında gerçekleşen hücre ölüm şekli olan mitotik katastrofi, hücre döngüsünün hatalı kontrol noktalarının bir kombinasyonu sonucunda meydana gelir. Mitotik katastrofi siklin B1 bağımlı kinaz, polo-like kinaz, Aurora kinaz, kaspazlar ve Bcl-2 ailesi gibi pek çok moleküler sistemle kontrol edilmektedir. Çalışma sonucunda kaspaz 3 , kaspaz 9 ve kaspaz 8'in ekspresyonlarının arttığını yine mitotik katastrofi ile ilişkili olduğu bilinen $\mathrm{Bcl}-2$ ailesi genlerinden olan $B A X, B A K$ ve NOXA'nın da ekspresyonlarının arttığı belirlenmiştir. Çalışmada ayrıca mitotik katastrofide anahtar bir rol oynadığı bilinen polo-like kinaz ailesinin bendamustin ile muamele sonrasında ekspresyon profillerindeki değişimi incelenmiştir. Tümor hücrelerinde aşırı ifade edildiği bilinen ve onkogenik özellik gösteren polo-like kinaz 1 (Plk1) ekspresyonunun ilaç ile muamele sonrasında 7.5 kat azaldığı ve tümör supresör özellik gösterdiği bilinen Plk2 geninin ekspresyonunun ise 23.1 kat artış gösterdiği belirlenmiştir. Elde edilen sonuçlara göre bendamustinin HL60 hücrelerinde mitotik katastrofide anahtar rolü olan genler üzerinde etkili olduğu ve ilacın apoptotik etkisinin yanında mitotik katastrofide de etkili olabileceği belirlenmiştir. Leoni ve ark. [14] lenfoma hücre serisi olan SU-DHL-1 hücrelerinin bendamustin ile muamelesi sonucu plk1 ekspresyon profilinde önemli düzeyde azalış saptamışlardır.

Bulgularımıza göre, alkilleyici bir ajan olan ve pürin analoğu özelliği gösteren bendamustinin HL60 hücreleriyle muamelesi sonrasında, ilacın hücrelere yüksek konsantrasyonda sitotoksik etkisinin bulunduğu gösterilmiştir. Ayrıca KLL ve mantle hücreli lenfoma hücrelerinde apoptotik etkisi olduğu bilinen bendamustinin HL60 hücreleri üzerinde de apoptotik etkisi bulunduğu Annexin $\mathrm{V}$ ve Apo Direct Tunnel yöntemleri ile belirlenmiştir.

Sonuç olarak; bendamustinin apoptozda intrinsik ve ekstrinsik yolaklar ile ilişkili olduğu bilinen kaspaz 8, kaspaz 3, kaspaz 9, NOXA, $B A X, B A K$ genlerinin ekspresyon profilinde anlamlı değişikliklere neden olduğu saptanmıştır ve bu değişimler doğrultusunda hücreleri apaoptoza yönlendirdiği düşünülmektedir. Buna ek olarak bendamustinin, mitotik katastrofide önemli role sahip olan ve son dönemde kanser ilaçlarının geliştirilmesinde alternatif hedef olarak sıkça bahsedilen plk1 geninin ekspresyon profilinde anlamlı bir değişikliğe sebep olduğu gösterilmiştir. Yine aynı kinaz ailesinin üyesi olan, AML de tümör supresör özelliği gösteren plk2 ekspresyonunda artışa sebep olduğu belirlenmiştir. Elde edilen sonuçlar doğrultusunda, bendamustinin HL60 hücrelerini hem apoptoza yönlendirmesi hem de apoptozdan kaçabilen hücreleri mitotik katastrofa yönlendirme potansiyelinin bulunmasının klinik açıdan umut verici olduğu düşünülmektedir.

Çıkar İlişkisi: Yazarlar çıkar ilişkisi olmadığını beyan eder. 


\section{Kaynaklar}

1. Ozegowski W, Krebs D. w-[bis-(chlorethyl)-aminobenzimidazolyl-(2)]-propionic or butyric acids as potential cytostatic agents. J Prakt Chem 1963; 20:178-186.

2. Hartmann $\mathrm{M}$, Zimmer $\mathrm{CH}$. Investigation of crosslink formation in DNA by the alkylating cytostatica IMET 3106, 3393 and 3943. Biochim Biophys Acta 1972;287:386-389.

3. Strumberg D, Harstrick A, Doll K, Hoffmann B, Seeber S. Bendamustine hydrochloride activity against doxorubicine-resistant human breast cancer cell lines. Anti-cancer Drugs 1996;7:415-421.

4. Koenigsmann M, Knauf W, Herold M, et al. Fludarabine and Bendamustine in Refractory and Relapsed Indolent Lymphoma-a Multicenter Phase I/II Trial of the East German Society of Hematology and Oncology (OSHO). Leuk Lymphoma 2004;45:1821-1827.

5. Hiraoka N, Kikuchi J, Yamauchi T, et al. Purine analoglike properties of bendamustine underlie rapid activation of DNA damage response and synergistic effects with pyrimidine analogues in lymphoid malignancies. PLoS One 2014;9:e90675.

6. Kost SE, Bouchard ED, LaBossière É, et al. Crossresistance and synergy with bendamustine in chronic lymphocytic leukemia. Leuk Res 2016;50:63-71.

7. Scutaru AM, Wenzel M, Scheffler H, Wolber G, Gust R. Optimization of the $\mathrm{N}$-lost drugs melphalan and bendamustine: synthesis and cytotoxicity of a new set of dendrimer-drug conjugates as tumor therapeutic agents. Bioconjug Chem 2010;21:1728-1743.

8. Inoue M, Honma $\mathrm{Y}$, Urano $\mathrm{T}$, Suzumiya. J.Japanese apricot extract (MK615) potentiates bendamustineinduced apoptosis via impairment of the DNA damage response in lymphoma cells. Oncol Lett 2017;14:792800.

9. Palombi M, Niscola P, Tendas A, et al. Simultaneous occurrence of large B-cell non-Hodgkin lymphoma and acute myeloid leukaemia in an elderly patient: complete remissions of both diseases by rituximabbendamustine regimen combined to hypomethylating therapy. J Chemother 2013;25:247-249.

10. Gaul L, Weber S, Bauman P, Emmerich B, Schmidmaier R. Bendamustine induces $\mathrm{G} 2$ cell cycle arrest and apoptosis in myeloma cells: the role of ATM-Chk2Cdc25A and ATM-p53-21 pathways. J Cancer Res Clin Oncol 2008;134:245-253.

11. Roue G, Lopez M, Milpied P, et al. Bendamustine is effective in p53-deficient $\mathrm{B}$-cell neoplasms and requires oxidative stress and caspase-independent signaling. Clin Cancer Res 2008;14:6907-6915.

12. Schwanen $\mathrm{C}$, Hecker $\mathrm{T}$, Huabinger $\mathrm{G}$, et al. In vitro evaluation of bendamustine induced apoptosis in B-chronic lymphocytic leukemia. Leukemia 2002;16:2096-2105.
13. Yang Q, Chen L S, Neelapu S S, Gandhi V. Combination of Pim kinase inhibitor, SGI-1776 and bendamustine in B-cell Iymphoma. Clin Lymphoma Myeloma Leuk. 2013;13:355-362.

14. Leoni LM, Bailey B, Reifert J, et al. Bendamustine (Treanda) displays a distinct pattern of cytotoxicity and unique mechanistic features compared with other alkylating agents. Clin Cancer Res 2008;14:309-317.

15. Cai B, Lyu H, Huang J, et al. Combination of bendamustine and entinostat synergistically inhibits proliferation of multiple myeloma cells via induction of apoptosis and DNA damage response. Cancer Lett 2013;335:343-350. 